\title{
Sociálně vyloučení v procesu mezigeneračního učení ${ }^{1}$ Intergenerational learning of socially excluded people

\author{
Kateřina Pevná
}

\begin{abstract}
Abstrakt: Příspěvek představuje úvodní vhled do tématiky mezigeneračního učení u sociálně vyloučených Romů, jemuž se autorka věnuje v rámci své disertační práce. Př́spěvek se zaměřuje na stručnou charakteristiku určujících teoretických koncepti̊, kterými jsou mezigenerační učení a sociální vyloučení. V rovině empirické pak popisuje metodologii výzkumu disertační práce především se zaměřením na dosavadní výzkumné kroky - vývoj od kvantitativního výzkumného designu směrem ke kvalitativnímu výzkumnému designu. V závěru příspěvku se věnuje prvotním zjištěním, která ovlivní další výzkumné kroky.
\end{abstract}

Klíčová slova: mezigenerační učení, sociální vyloučení, generace, rodina

\begin{abstract}
The paper introduces a topic of my dissertation which is an intergenerationnal learning of socially excluded people. First of all I briefly focus on two main theoretical concepts, which are intergenerational learning and social exclusion. Then I explain a methodology of research of dissertation thesis and finally also some very first findings.
\end{abstract}

Keywords: intergenerational learning, social exclusion, generation, family

\section{1 Úvod}

Příspěvek představuje úvodní vhled do tématiky mezigeneračního učení u sociálně vyloučených Romů, jemuž se autorka věnuje v rámci své disertační práce. Téma sociálního vyloučení, tedy konceptu, který je v dnešní době jedním z hlavních témat diskusí o sociálních systémech a boji s chudobou naprríč celou Evropskou unií, se zde propojuje s tématem mezigeneračního učení, tedy konceptem, který se na českém vědeckém poli teprve rodí ${ }^{2}$. Ústřední výzkumnou oblastí je podoba mezigeneračního učení v rodinách sociálně vyloučených Romů. Konkrétně pak co se v rodině každý člen učí, od koho se v rodině učí, resp. jakou roli hrají jednotlivé generace $v$ učení v rodině a jakým způsobem se do mezigeneračního učení $v$ rodině zapojují; v neposlední řadě také jaké faktory ovlivňují mezigenerační učení v rodině sociálně vyloučených Romů. Tato témata jsou pak řešena v rámci minimálně třígeneračního pohledu, tedy dětí, rodičů a prarodičů.

\footnotetext{
${ }^{1}$ Tento př́ispěvek vznikl za podpory Děkanského studijního grantu Filozofické fakulty Masarykovy univerzity v Brně a v rámci projektu Škola: výzkum vnitřních procesů a vnějších podmínek jejího fungování (GA406/09/H040) financovaného Grantovou agenturou České republiky. Autorka děkuje za poskytnutou podporu.

${ }^{2}$ Tématu mezigeneračního učení se v současnosti věnuje prof. PhDr. Milada Rabušicová, Dr. v rámci projektu Mezigenerační učení: děti, rodiče, prarodiče v neformálním vzdělávání a informálním učení, podpořeného Grantovou agenturou České republiky.
} 


\section{Teoretický vhled do zkoumané problematiky}

Tato kapitola stručně představí základní teoretický rámec zkoumané problematiky. Nejprve bude definován pojem mezigenerační učení a jeho základní charakteristiky. Následně bude objasněn pojem sociálního vyloučení společně s charakteristickými rysy kultury chudoby, jež se s tímto konceptem pojí.

\subsection{Mezigenerační učení}

Mezigenerační učení je „proces, skrze který jedinci všeho věku získávají dovednosti a znalosti, ale také postoje a hodnoty, a to z denních zkušeností, ze všech možných dostupných zdrojů, a ode všech vlivů v jejich vlastních žitých světech" (Hatton-Yeo, 2008, s. 3). Co tedy především vymezuje mezigenerační učení od jiných typů učení, je jeho zaměření právě na jednotlivé aktéry, tedy na zástupce různých generací, kteří do procesu učení aktivně vstupují. S Ramonem a Turrinim (in Rabušicová, 2010), kteří poukazují na to, že mezigenerační učení je vlastně pouze postmoderní označení pro proces předávání/přebírání dědictví po předcích, kdy sociální a kulturní znalost je předávána od starších k mladším, dnes již nelze souhlasit. Je nutné jít v jejich uvažování o krok dále, a to zejména v souvislosti s rozvojem informační společnosti, kdy se role mladší a starší generace proměňuje. Na tomto základě tak musíme mezigenerační učení vnímat jako obousměrný proces předávání znalostí, dovedností a zkušeností mezi generacemi vzájemně.

Z hlediska zasazení mezigeneračního učení do širšího kontextu můžeme v souvislosti s ním hovořit o oblasti verbálně-kognitivní, sociální a senzomotorické (Průcha, 2005). Dále o rovině neformální a informální a rovněž můžeme poukázat na jeho všeživotní a celoživotní charakter (srov. Bostrom, 2009).

\subsection{Sociální vyloučení a rysy kultury chudoby}

Autorkou stručně nastíněné procesy mezigeneračního učení jsou vztaženy $\mathrm{k}$ sociálně vyloučeným osobám, kterými jsou v kontextu České republiky především Romové. V odborné literatuře se můžeme často setkat s označením sociálně vyloučená romská populace či komunita apod. Hned v úvodu je ovšem nutné zmínit, že se autorka připojuje k odborníkům jako je Moravec (in Hirt, 2006) či Klečková (2009), tedy že nelze zaměňovat problém chudých městských aglomerací s romským problémem. Vedle toho ovšem nerezignuje na roli romství u sociálně vyloučených osob. Charakteristiku cílové skupiny tak lze označit jako průsečík mezi zmiňovanými dvěma základními kritérii, tedy romstvím a sociálním vyloučením.

Sociální vyloučení je proces, který určité jednotlivce, rodiny, př́ípadně skupiny či celá lokální společenství (komunity) omezuje v př́stupu ke zdrojům, jež jsou potřebné pro participaci na sociálním (brání sdílet určité statusy a sociální instituce), ekonomickém (je zdrojem chudoby a vyloučení z životního standardu a životních šancí, obvykle marginalizací na trhu práce a nezaměstnaností) i politickém životě společnosti. Děje se tak díky omezení občanských, politických i základních lidských práv - upřením sdílet společenský a kulturní kapitál, vzdělanost i hodnoty společnosti (srov. Navrátil, 2003; Sirovátka, 2004; Mareš, 2000). Sociální vyloučení je považováno za dynamický a mnohodimenzionální proces (např. v porovnání $\mathrm{s}$ jednodimenzionálně pojímanou chudobou). Jeho jednotlivé dimenze se navzájem podporují a vyloučení z jedné oblasti participace na životě společnosti, např́klad z trhu práce, může nastartovat proces vylučování z oblastí dalších. Osoby, které jsou tímto jevem zasaženy nebo ohroženy, sdílejí specifické životní podmínky a přijímají tak životní strategie (vzorce chování, životní hodnoty a principy), které jim umožňují se na tyto podmínky adaptovat. U sociálně vyloučených lokalit tak můžeme sledovat paralely 
s charakteristikami kultura chudoby, již jako teoretický koncept v 60. letech minulého století vymezil antropolog Oscar Lewis. Kultura chudoby je typická řadou rysů, které její nositelé sdílejí (Klečková, 2009). Tito zpravidla nejsou členy politických stran, nenavštěvují veřejné instituce (banky, restaurace, obchodní domy, ad.), obecně lze říci, že nesdílí kulturu majoritní společnosti. Formalizovaný institut manželství se v jejich postavení jeví jako nepraktický a z ekonomického pohledu nevýhodný. Vznikají mezi nimi spíše volné neoficiální partnerské svazky. Odlišná je také podoba dětství, resp. jeho vnímání v kultuře chudoby. Na rozdíl od moderní, zejména západní společnosti, kde je obvykle dětství vnímáno jako období života, během kterého je dítě všemožně chráněno a podporováno (Lewis in Klečková, 2009), v prostředí kultury chudoby je dítě chápáno rovněž ekonomicky, a to jako důležitý zdroj pracovní síly a bohatství. Pokud bychom se zaměřili na některé základní demografické charakteristiky, pak lze $\mathrm{v}$ těchto lokalitách sledovat nedostatečné vzdělání a nízkou profesní kvalifikaci. Rovněž tak nižší střední délku dožití (Kalibová in Budilová, 2009) a naopak vysokou míru porodnosti (Kalibová in Budilová, 2009), která má návazně stěžejní vliv na strukturu domácností. Tyto mají oproti majoritní společnosti větší počet členů, což se promítá do jejich životního stylu, vč. úrovně bydlení. Nezřídka obývá malometrážní byt v brněnské sociálně vyloučené lokalitě i deset osob všech generací (VeryVision, 2008).

\section{Vývoj metodologie výzkumu}

Prvotním úmyslem pro uchopení výše zmíněných výzkumných témat bylo využití kvantitativního výzkumného designu, konkrétně dotazníkové šetření. Provedené pilotní šetření však ukázalo nevhodnost tohoto př́istupu v rámci první fáze výzkumu. Zmíněné pilotní šetření bylo realizováno v období květen - červenec 2011, a to ve dvou rovinách. V první rovině byli osloveni experti, tedy osoby, které jsou s cílovou skupinou výzkumu v každodenním kontaktu. Jednalo se o terénní sociální pracovníky a pedagogické pracovníky jedné z brněnských nevládních organizací zabývající se prací se sociálně vyloučenými Romy. Záměrně byli voleni zástupci těchto profesí. První z nich se zabývají prací s dospělými osobami, tedy střední a nejstarší generací. Druzí jmenovaní se zabývají prací s generací nejmladší. Úkolem těchto vybraných expertů bylo hodnocení vhodnosti výzkumného nástroje pro cílovou skupinu. $\mathrm{V}$ druhé rovině pilotního šetření byla realizována samotná distribuce dotazníku mezi cílovou skupinou. Z realizovaných rozhovorů s těmito pracovníky a z osobní administrace dotazníku mezi respondenty $\mathrm{z}$ řad cílové skupiny vyplynulo, že použití dotazníků by nepřineslo kýženou kvalitu vhledu do sledované problematiky. Důvodů bylo hned několik a shodují se na nich výsledky obou provedených rovin pilotáže. Experti i samotní respondenti označili jako nevhodné použití otevřených otázek v dotazníku. Důvodem byla neochota potenciálních respondentů zabývat se určitým tématem prŕliš dlouho. V odpovědích na otevřené otázky se tak objevovaly pouze jednoslovné odpovědi nebo odpovědi typu „nevím“, „nic“ apod. Rovněž délka dotazníku (20 položek) byla hodnocena jako př́liš dlouhá, a to $\mathrm{z}$ obdobného důvodu. Kratší verze dotazníku by ovšem nepostihla sledované oblasti. Další z důvodů byl také počet respondentů ochotných vyplnit dotazník. Zejména $\mathrm{z}$ řad expertů zaznívaly hlasy o neochotě budoucích respondentů cokoli vyplňovat, plynoucí z jejich vžitého strachu $\mathrm{z}$ formulářù apod., se kterými se setkávají na většině institucí, s nimiž přicházejí do kontaktu.

Na základě výsledků pilotního šetření tak došlo k revizi výzkumných metod, a to tak, že první fáze výzkumu je realizována v podobě kvalitativního výzkumného designu. Autorka v této fázi oslovila několik prvních respondentů, kterým kladla poměrně široce otevřené otázky s důrazem na precizaci struktury dalších výzkumných kroků. 


\section{Determinanty budoucích výzkumných kroků}

$\mathrm{V}$ rámci prvotního vstupu do terénu byly v souladu s výše zmíněnou metodologií provedeny první čtyřri rozhovory v délce $70-90$ minut. Konverzační partneři byli vybráni záměrným výběrem na základě již nastíněných kritérií, a to prostřednictvím doporučení expertů, kteří usnadnili vstup do terénu. Na základě těchto rozhovorů lze vymezit některá témata, která ovlivní budoucí výzkumné kroky.

Jednu z diskutovaných oblastí představovali aktéři mezigeneračního učení. Z již prvních realizovaných rozhovorů lze vyvodit, že téma mezigeneračního učení v romské rodině bude definováno $\mathrm{z}$ hlediska jeho aktérů poměrně široce, a to zejména s ohledem na fungování romské rodiny jako takové. Zatímco ve většinovém českém, potažmo euroamerickém kontextu je rodina vnímána především jako rodiče a jejich děti (rodina nukleární), v př́padě romských rodin je tuto skupinu osob nutno značně rozšíritit. Romská rodina je ,mnohem větší, vícegenerační a na rozdíl od majoritní rodiny je také více ekonomicky a sociálně provázaná“ (Navrátil \& Šišláková in Sirovátka, 2004, s. 141). Právě systém rodinných, resp. rodových vazeb je typický pro romské komunitní soužití snad ještě více než charakteristika skrze jednotlivé subetnické skupiny. Nelze tedy v souvislosti s tímto faktem nezmínit systém endogamních rodů (rod = fajta), sledovaných v romských osadách (srov. Hirt 2004, 2006; Budilová, 2009; Kobes, 2010). Fajta se skládá z mnoha „komplexních“ rodin, které zahrnují nukleární rodiny každé generace. I tento systém lze sledovat v terénu sociálně vyloučených romských lokalit v Brně, kde byl pilotní vstup do terénu realizován. Jak uvádí mimo jiné výpověd' jedné z respondentek: „... holka když začne chodit s tím klukem, tak vlastně ten kluk př́de, třeba na návštěvu a začne, ted' se ho otec třeba bude ptát a vodkad' sě̌ a z jaké rodiny seš a to a ted' se takhle bavěj jo... tam je třeba rodina Horvátova, rodina Davidova, rodina Peštova, rodina Filova, jo prostě takový ty rodiny. Tak jako a ted' von se zeptá, zjaké rodiny ty pocházís. A von ted'ka řekne, já sem z Brna z rodiny přiklad Čonkové, že jako jo Čonkovi, a ted' se zeptat, že kterýho Čonky, protože oni jich je hodně těch Čonků jo a von ti řekne já nevím, třeba z Josefa... “(R1).

Další z diskutovaných oblastí je silný vliv genderových rozdílů, resp. silný přenos genderových stereotypů ve vnímání ženské a mužské role, které zřejmě do budoucna významně ovlivní i výběr dalších konverzačních partnerů. $\mathrm{S}$ ženskou rolí se pojí péče o domácnost jako úklid, nákup, vaření a rovněž péče o děti, popř. mladší sourozence již od útlého věku. S mužskou rolí pak zejména obstarávání finančních prostředků. Partnerka má tedy na starosti veškeré úkony spojené s chodem domácnosti a výchovou dětí i $\mathrm{s}$ řešením problémových situací i existenčního typu. Tento fakt např. dokládá i struktura klientů, resp. klientek nevládních organizací, které pracují s touto cílovou skupinou, kdy v jejich struktuře převládají ženy jako zadavatelky zakázky (srov. Výroční, 2010).

Na základě prvotního vstupu do terénu byla upravena osnova polostrukturovaných rozhovorů. $\mathrm{V}$ následných výzkumných krocích bude autorka realizovat tyto rozhovory se zástupci minimálně tří generací směrem $\mathrm{k}$ zodpovězení nastolených výzkumných témat.

\section{Literatura}

Bostorm, A. K. (2009). Lifelong learning, intergenerational learning and social capital - from theory to practise. Dostupné z http://www.interped.su.se/publications/BostromNo.61.pdf

Budilová, L., \& Jakoubek, M. (2009). Cikánské skupiny a jejich sociálni organizace. Brno: Centrum pro studium demokracie a kultury.

Hirt, T., \& Jakoubek, M. (2004). Konec (ne)jednoho mýtu: tractatus culturo(mo)logicus. Praha: Socioklub.

Hirt, T., \& Jakoubek, M. (2006). Romové v osidlech sociálního vyloučení. Plzeň: Aleš Čeněk.

IQ Roma servis (2010). Výroční zpráva 2010. Brno: IQ Roma servis. 
Klečková, M. (2009). Př́stup Romů ke svému „Romstvi“" (Diplomová práce). Dostupné z https://is.muni.cz/auth/th/180765/ff_m/

Kobes, T. (2010). Fajta a povaha př́buzenství obyvatel východoslovenských romských osad. Sociologický časopis, 46(2), 235-255.

Mareš. P. (2000). Chudoba, marginalizace, sociální vyloučení. Sociologický časopis, 36(3), 285-297.

Navrátil, P. (2003). Romové v české společnosti. Praha: Portál.

Průcha, J. (2005). Moderní pedagogika. Praha: Portál.

Rabušicová, M., Kamanová, L., \& Pevná, K. (2010). Čas a věk hraje roli: tři generace se učí v kurzech. Studia paedagogica, 15(1), 125-146.

Sirovátka, T. (2004). Sociální exkluze a sociální inkluze menšin a marginalizovaných skupin. Brno: FSS MU.

Šimíková, I. (2004). Mechanismy sociálního vyčleňování romských komunit na lokální úrovni a nástroje integregace. Brno: Barrister \& Principal.

VeryVision (2008). Identifikace sociálně vyloučených lokalit a zpracování jejich mapy ve městě Brně. Ostrava: VeryVision, s.r.o.

\section{Kontakt}

Mgr. Kateřina Pevná

Masarykova univerzita

Filozofická fakulta, Ústav pedagogických věd

A. Nováka 1, Brno 60200

e-mail: pevna@phil.muni.cz

\section{Bibliografické údaje}

Pevná, K. (2011). Sociálně vyloučení v procesu mezigeneračního učení. In T. Janík, P. Knecht, \& S. Šebestová (Eds.), Smišený design v pedagogickém výzkumu: Sborník přispěvkù z 19. výroční konference České asociace pedagogického výzkumu (s. 484-488). Brno: Masarykova univerzita.

Dostupné z: http://www.ped.muni.cz/capv2011/sbornikprispevku/pevna.pdf

doi: 10.5817/PdF.P210-CAPV-2012-44 